\title{
Paris - London: empirical philosophy, invention and the Hartlib Circle
}

Paris-Londres : le cercle Hartlib, la philosophie empirique et l'invention

\section{Anthony Turner}

\section{(2) OpenEdition}

\section{Journals}

Electronic version

URL: http://journals.openedition.org/artefact/1286

DOI: $10.4000 /$ artefact. 1286

ISSN: 2606-9245

Publisher:

Association Artefact. Techniques histoire et sciences humaines, Presses universitaires du Midi

\section{Printed version}

Date of publication: 30 May 2018

Number of pages: 123-150

ISBN: 978-2-7535-7494-6

ISSN: 2273-0753

\section{Electronic reference}

Anthony Turner, «Paris - London: empirical philosophy, invention and the Hartlib Circle », Artefact

[Online], 7 | 2017, Online since 30 January 2019, connection on 06 March 2020. URL : http:// journals.openedition.org/artefact/1286 ; DOI : https://doi.org/10.4000/artefact.1286 


\title{
Paris - London: empirical philosophy, invention and the Hartlib Circle
}

Anthony TURNER*

\begin{abstract}
Using the papers of Samuel Hartlib, the author examines the empirical research into the natural world affected in France and England during the early $17^{\text {th }}$ century, the making of the instruments needed for this research, and the transmission of technical ideas between France and England.
\end{abstract}

Keywords : Hartlib, Gassendi, Mersenne, Oldenburg, making of instruments, transmission, magnetism, music.

\section{Résumé. Paris - Londres : le cercle Hartlib, la philosophie empirique et l'invention}

À travers les papiers de Samuel Hartlib, l'auteur examine les recherches empiriques sur la nature menées en France et en Angleterre dans la première moitié du XviI ${ }^{\mathrm{e}}$ siècle, la production des instruments nécessaires pour de telles recherches, ainsi que la transmission des idées techniques entre la France et l'Angleterre.

Mots-clés : Hartlib, Gassendi, Mersenne, Oldenburg, fabrication d'instruments, transmission, magnétisme, musique.

\footnotetext{
*. Historien indépendant, Anthony Turner travaille actuellement sur un dictionnaire bio-bibliographique des facteurs d'instruments de précision français et suisses, 1430-1930; sur une histoire des montres émaillées au XVII ${ }^{\mathrm{e}}$ siècle (avec Catherine Cardinal) et sur les astrolabes en France au Xvi ${ }^{\mathrm{e}}$ siècle. Son catalogue d'instruments mathématiques dans les collections de la Bibliothèque nationale de France est sous presse. Contact : [anthonyturner@orange.fr].
} 
"Seeing you care not much for ye philosophicall discourses of our Club, you are not

looke for many reall Experiments from Frenchmen"

Henry Oldenburg's remark, in one of his regular letters to Hartlib reporting philosophical and cultural news and events garnered while living in Paris during 1659 as tutor to Robert Boyle's nephew Richard Jones, seems dismissive but is perhaps only ironic. Oldenburg, who had been in the city since April, had already had time to discover the range of possibilities it offered, and was just beginning to be accepted in its cultural circles. On 18 June, a week before his letter to Hartlib, he had described to the lawyer Pierre Saporta (1613-c. 1685), in Castres, meetings that he had attended at the private, but nonetheless, regular semi-permanently structured discussion circle that met in Habert de Montmor's town residence for philosophical discourse and discussion, and at the daily assemblies in the Hôtel of the President de Thou "where everything indifferently is discussed, but mainly what goes on in the world and newly published interesting books ${ }^{2 \prime}$. He described in some detail an account of vision given by Jacques Rohault at one of his regular weekly lecture-demonstrations, which had included the dissection of an eye and experiments with lenses ${ }^{3}$. If initially Oldenburg was somewhat disappointed by the level of activity in chemical medicine that he found in Paris Hic Parisijs multa promittunt, sed pauca præstant ('here in Paris many promise much, but few perform $)^{4}$, it is clear from some other of his remarks that even if he was not always well-informed ${ }^{5}$, there was a great deal happening in Paris to hold his interest.

Less so perhaps for Samuel Hartlib. Oldenburg's remark quoted at the beginning is clearly a response to a reflection by Hartlib in a now lost letter (probably that of 13 June 1659), a disgruntled comment no doubt on the penchant for philosophising that Oldenburg had reported from the Montmor Academy. The "reall Experiments" that were not to be expected in France were experiments such as Hartlib would accept as 'reall', which was not necessarily the same as those that savants in the French capital thought they needed. Other slightly jaundiced remarks by Oldenburg are also not automatically to be taken at face value. To Boyle on 23 July he wrote that "We have severall meetings here of philosophers and statists ${ }^{6}$ wch I carry yr nevew to, for to study men, as well as books; though ye French naturalists are more discursive, yn active or experimentall. In the meane time the Italian proverb is true: le parole sono femine, le fatti maschii ${ }^{7}$." Like his comment to Hartlib, this inelegant remark probably applies specifically to the Montmor and Thuanian meetings where emphasis was indeed placed on discussion and philosophising. Nonetheless as Oldenburg would shortly discover, experiments (though more often for demonstration than for investigation) were performed at the Montmor assemblies to which Rohault took his apparatus, and which, in the very year that Oldeburg was present was turning, following the death of Gassendi in 1655 and the violent confrontation of 
Roberval and de Montmor in late 1658, away from speculations about causes which could easily lead to dissension, towards research into bodies, techniques and instrumentation which offered a neutral, non-divisive terrain for activity ${ }^{8}$.

The Montmor academy however was not co-extensive with activity in natural philosophy in mid- $17^{\text {th }}$ century Paris, and Oldenburg's view was not entirely an objective one. In his letters he comments on what he sees in ways that he expects to be acceptable to his correspondents. This means that in writing to Hartlib he reports on practical discussions (such as that he had with Roberval concerning Descartes' views on hyperbolical lenses) ${ }^{9}$, on investigative experiments, on inventions, on chemical preparations and particularly on chemical medicines. Philosophising, rational discussion seeking causes, explanations, theories seeking the reasons of things however were less welcome. Hartlib's utilitarian orientation, his belief in the perfectibility of human life in society through

\section{Approaches}

The world-view of the cultural nation in mid-17 th century France was a patchwork of compromise and contradiction. Aristotelianism, which still determined the categories of knowledge and the structure of institutional learning, was only just beginning to be challenged by a thorough-going mechanism, and the force of this attack was partly dissipated by the dissension of its two main proponents, Gassendi and Descartes. Compromises had already industry, humility and dependence on God, meant that a good deal that was essential to French natural philosophy in the mid-century would be uncongenial to him. Fundamentally, it may be for this reason that, the practical difficulties of communication with a catholic state, language, correspondence and correspondents set apart, what was drawn by Hartlib and his circle from France is substantially rather little - a certain amount of news, much of it trivial, information about publications and research, knowledge of institutions and events. It was the last that was probably the most important for it was knowledge of institutions such as Renaudot's Bureau d'adresse, of activities such as lenspolishing that were provoking serious attention in Paris, and the efficacy of Mersenne's correspondence network that provided essential inspiration, models for emulation and much needed psychological and emotional reassurance for Hartlib's similar undertakings.

been made between the old and the new cosmology ${ }^{10}$, but traditional galenic and iatro-chemical medicine were in a state of open hostility. Nonetheless this did not prevent a medical traditionalist such as Guy Patin from also being a free-thinker on amiable terms with advanced mechanists such as Gassendi and Neuré ${ }^{11}$. Advanced techniques of research, of thinking or of demonstration could co-exist with traditional practices and beliefs, creating an intellectual 
confusion which compounded social and cultural insecurity. One distinctive element of apparent modernity, but, as the correspondence of Mersenne and Theodore Haak would reveal, in fact already having a long history, was an increasing emphasis on empirical methods and procedures, an emphasis that encouraged an experimental approach to nature and with it an interest in the techniques of artisans and in the development of instruments, methods and tools for carrying out experiments.

Experiment, empiricism, artisanal techniques especially as these could be viewed as useful and improvable, are all concepts which seem congruent with the ideas of Hartlib and his circle. The key element - empiricism needs however to be somewhat more closely defined. In the $17^{\text {th }}$ century it can be seen as that approach to the natural world which insists that all reasoning about it should be based on sense experience. This experience may or may not be experimentally derived, with or without the use of instruments or apparatus, but it is always supposed to be derived from things. It is never $a$ priori although it may be derived with the help of hypotheses. Such a definition embraces both observational studies such as astronomy and botany, and manipulative ones such as anatomy and chemistry. Such empiricism is an attitude to nature, a habit of mind, which is to some extent independent of the philosophy used to order and interpret the phenomena observed or discovered, be it mechanical, hermetic, humanist, Aristotelian, mathematical or an amalgam of some or all of them. Such empiricism can also draw on a variety of sources, casual or programmed observation, artisanal procedures, controlled experimentation ${ }^{12}$.

Because of the noisy propaganda of the self-elected followers of Francis Bacon in mid- $17^{\text {th }}$ century England, historians of the development of natural philosophy in that country have been unable to avoid empiricism. Indeed so much was it vaunted by otherwise apparently unproductive enthusiasts, that there has even been a historiographical tendency to play down its importance. In France, although the empirical tendency was just as widespread, it was rarely presented as an exclusive way for arriving at truth, but was rather used as a technique in the building of philosophical explanations, not being perceived as in itself a philosophy. As a result, although historians of the early years of the Académie royale des sciences such as Harcourt Brown, René Taton, Roger Hahn and Trevor McClaughin ${ }^{13}$, have been fully aware of the highly empirical nature of that body in its early years as of its predecessors, the sources of that orientation in the earlier decades of the century have been little explored. Because of the accident that it was the philosophical writings of the two greatest savants of the midcentury, Descartes and Gassendi that were of primary interest to their $18^{\text {th }}$ and $19^{\text {th }}$ century commentators, their empirical work - which is fundamental to all Gassendi's output and is not negligible in that of Descartes ${ }^{14}$ - has been less studied and with it the whole empirical investigative movement of which it was a part and from which it emerged. 


\section{A model: Peiresc}

Empiricism was indeed just as widespread in France during the middle decades of the $17^{\text {th }}$ century as it was in England. Although its antecedents reach back to the $16^{\text {th }}$ century, to Ramus and Bernard Palissy ${ }^{15}$, the immediate source is Peiresc and the network of observers that he organised in Provence and elsewhere. Peiresc, the equivalent in his generation of Mersenne and Hartlib in theirs, was universally curious and universally communicative. His correspondence, which reached across Europe and even into the Middle East, was voluminous so much so that, although seven stout volumes and several supplements have been published since 1887 it is still not entirely available. Matter for the thousands of his letters was supplied from the hours passed observing, dissecting, recording and comparing natural and artificial phenomena. Peiresc's researches ranged throughout the natural and human worlds from the satellites of Jupiter to the eyes of the chameleon, from Roman calculating instruments to renaissance medals, from Persian cats to Egyptian antiquities and geological specimens. A compulsive collector of both books and objects and with the means to pursue them, Peiresc was no magpie. Behind his accumulating was a consuming desire to understand the structure and organisation of the natural world and the social and spatial relations of ancient societies ${ }^{16}$.

Understanding for Peiresc came from observation and experience, from the empirical examination of things, not from ideas and theories about them. If his innate humanism meant that all phenomena would be compared with those recorded in the writings surviving from Classical and Later Antiquity ${ }^{17}$, what he most valued was precision of depiction whether verbal or pictorial ${ }^{18}$. It was a similar concern that he sought in his correspondents and collaborators, and it was this desire for precise, detailed, observed knowledge that led him into some long programmes of investigation. If the most important of these was probably his exploration of some of the avenues for astronomical research opened up by Galileo and the telescope, carried out in collaboration primarily with Joseph Gaultier and Gassendi, other undertakings such as those on the anatomy of eyes and the nature of vision carried out with Gassendi, the attempt to map the moon with the help of Gassendi and Claude Mellan, or to co-ordinate observations on the nature of winds using a whole network of local observers in Provence, are just as indicative of his approach $^{19}$.

Observe, record, organise other competent observers to observe and record, co-ordinate the results and communicate them so that they shall be of use. Such was the approach of Peiresc who may, to the Hartlib circle, have seemed something of a role model of the virtuous, Christian humanistphilosopher, commonwealth-gentleman. Certainly in 1651 Thomas Smith (1624$1661)^{20}$ was discussing with Hartlib the possibility of translating Gassendi's biography of him into English. Smith is 'very unwilling' not to please Hartlib in the matter (which implies that it was Hartlib who was pressing him to 
undertake the task), but although he had intended to make an attempt at it he has been distracted by other literary activity. Moreover he is despondent about getting any help with it from his Cambridge colleagues Ralph Widdrington ${ }^{21}$ and Henry More ${ }^{22}$ 'and people think that there will be no sale for an Engl translation as long as the Latin (which is reprinting) can be had cheaply ${ }^{\prime 23}$. Perhaps the only person really qualified to do it was Thomas Fuller (author of the Holy Warre), but if he will not undertake it then Smith will, even though no English publisher will look at it while the Latin version is in press. Eventually the work was translated by William Rand, an unlicensed London physician associated with Hartlib and Bejamin Worsley, who had earlier translated material for the third edition of Hartlib's Legacy (1655). It was published in 1657 with a dedication to John Evelyn, another figure in Hartlib's circle and one who, by the nature of his humanism and universal curiosity, could be assimilated to Peiresc ${ }^{24}$.

\section{Mersenne, the mid-century and instrumentation}

If Peiresc's activities struck a respondent chord with those of Samuel Hartlib, they were similarly consonant with those of his younger contemporary and correspondent Marin Mersenne. The similarities will be evident. Like Peiresc, Mesenne observed, and recorded, communicated with other investigators and provided the means by which they could communicate with each other. Recipient himself of Peiresc's patronage in the publication of his works on music ${ }^{25}$, Mersenne encouraged others to make their writings known and constantly goaded his correspondents to write, translate and publish. Inevitably there were differences of emphasis. More intellectual than Peiresc, Mersenne, like Gassendi, gave a greater place to "philosophising", reflecting about the reasons for things, than Peiresc, and a far greater importance than either of them to mathematics ${ }^{26}$. Even so Hartlib, and the members of his circle, would have responded strongly to Mersenne's enthusiasm for digests of knowledge, for coordinated, subsidised, research by many hands, and to the fundamental place he accorded to experiment and observation. In an expansive moment to Theodore Haak, Mersenne outlined some of these concerns. He described a plan for correcting faults in encyclopedic works such as those of Jerome Cardann ${ }^{27}$ or Giovanni Battista della Porta ${ }^{28}$, another for noting in philosophical and theological works passages which were merely probable, those which were unnecessary, and those which were "absolutely true". "But', he continues, 'there is no pleasure in that if one does not meet with other people having the same aim; for there are experiments to be made in medicine, chemistry, tillage, mechanics, etc; such that one man alone cannot do if he is not subsidised in it by a King or a Republic ${ }^{29 \prime \prime}$.

The empirical world of Mersenne and the savants of mid- $17^{\text {th }}$ century France whom he wished to see work together, 
was filled with measurements - of bricks and metals before and after heating, or of human bodies alive and dead to see if the latter gained in weight; of observations of the behaviour of magnets, the movements of the heavenly bodies, (the positions of which could also be measured), of the behaviour of mercury in tubes, or the crystalline structure of snowflakes. Bizzarities in the form of monstrous births or outlandish medical conditions were regularly recorded and some systematic programmes of investigative research, such as those into the figuring of lenses, were undertaken. If they were not all particularly fruitful, they nonetheless had the common aim of dispelling popular error. This was a primary objective.

Measurement, observation, recording however were not simple, nor inexpensive, activities. All required instruments and apparatus. Empirical investigation of the natural world at anything beyond the most superficial level involved the acquisition, development, understanding and use of a wide range of instruments. It therefore implied, and required, the services of several different craft skills at a high level of competence. It was here in the artisan world of production, of mechanics and technicians that the new empiricism of natural philosophers met, and fused, with the old-established activity of practical mathematics.

Traditional natural philosophy, that invented by the friars in the $13^{\text {th }}$ century and institutionalised in the new universities ${ }^{30}$, had little need for instruments except for some demonstration devices such as the armillary sphere in astronomy. The rapid growth of interest in astrology in the fourteenth and fifteenth centuries however was potent in increasing demand, particularly for the astrolabe ${ }^{31}$, and the diffusion of the new geared, weight-clocks provoked a demand for sundials to set them. This rising demand led to the appearance of a new group of skilled craftsmen specialised in the making of clocks, sundials, astrolabes, globes, armillary spheres and equatoria, which all required engraving skills and a modicum of mathematical knowledge. The development of this group was favoured by the Renaissance rediscovery of ancient mathematics and the spread of mathematical techniques to a variety of practical activities such as navigation, fortification, siege-craft, land surveying and bookkeeping. In the history of instruments and instrument-making, what characterises the Renaissance is less the quite large number of would-be novel, but actually often rather traditional devices proposed by ambitious inventors, but the establishment of permanent workshops specialised in the production of such items of small scale but relatively precise technology, and the appearance of the mathematical practitioner, a 'technical-professional' who had hardly existed before ${ }^{32}$.

Neither France nor England was in the vanguard of these developments. Although isolated instances of sophisticated early activity occur such as the, as yet not localised, workshop that produced a small group of astrolabes associated with Edward III of England, that which produced the quadrants associated with the court of Richard II of England, and the late fourteenthearly fifteenth century workshop of 
Jean Fusoris ${ }^{33}$, in neither country can anything approaching permanent workshops producing a range of items in precision technology be discerned before the second half of the $16^{\text {th }}$ century. Such workshops, which perhaps first emerged in Italy among the artists shops surrounding the courts such as that of the Volpaia dynasty or, slightly later, those of Falconi and G.B. Giusti ${ }^{34}$, were nonetheless mixed in both production and demand, and workmen tended to be polyvalent. Philippe Danfrie (c. 15251606), the Paris maker about whom most is known from this period was by trade a type-cutter and founder who produced innovative 'civilité' printing types, made dies for coins, medals and jetons, and tools for book-binders as well as mathematical instruments. In 1582 , he was appointed mint-master to Henri III (Contrôleur des monnaies), a post that he retained under Henri IV. At the same time he continued making instruments and, exceptionally among makers, invented two new instruments, one of which was to have a long and successful future, and published them in a book, which he wrote and printed himself using type that he had also cut and cast himself $^{35}$.

Philippe Danfrie was an outstanding maker and would have been at any period. In the variety of his activities however he was entirely typical of his age. The men who serviced the mathematical practitioners of the $16^{\text {th }}$ and $17^{\text {th }}$ centuries were seldom yet the specialists they would become in the $18^{\text {th }}$ century. Rather they were general 'mechanicians' building up a range of competences on the basis of training in one particular activity. Many of them were primarily horologists, others general metalworkers, founders or engravers, still others specialists in ivory, tortoiseshell or precious woods, others again were enamellers or glass-workers. Whatever the case, it is the variety of skills and the adaptability of their possessors, which was of importance to Peiresc, Mersenne and the members of their circles, the increasing number of amateurs of nature, of mathematical practitioners, of investigators and inventors in Paris and the regions. Capable artisans in precision technology would be called upon to respond both to new needs for instruments and apparatus stemming from savants and natural philosophers, and to the development of inventions, tools, and machines requisite for an expanding society intent upon improvement.

\section{Hartlib and his Paris correspondents}

Knowledge of the artisan world of skilled craftsmen that underlies, and to some extent made possible the philosophical activities of Mersenne and his friends is still somewhat limited.
It is a patchwork with many holes rather than a tapestry of harmonious design. Some of the holes though can be filled with information deriving from Hartlib's papers so it is unfortunate 
that his contacts with France were not more regular, substantial and direct. In the 1630s, although he was not totally without news from Paris, what Hartlib learnt was spasmodic and without continuity. It was also largely anecdotal, even sensational, rather than ameliorative of man's spiritual or physical condition. Thus he was informed of the wild prophecies, which led their utterer to the Bastille, that the French king should become the Holy Roman Emperor while the Turks drove the Pope out of Italy to Avignon ${ }^{36}$, but knew no more of Gassendi in 1635 than that Henry Gellibrand esteemed him highly "as one of the best Astronomers of France ${ }^{37 \prime \prime}$, and nothing at all about the appointment by Richelieu in 1634 of a special committee of mathematicians to examine the claims of Jean Baptiste Morin (1583-1656) to have found a solution to the Longitude problem ${ }^{38}$. Since Morin's was probably the most important - and the most publicised attempt to resolve the longitude problem in either France or England during the early $17^{\text {th }}$ century, and since Hartlib was assiduous in noting developments in this subject being particularly interested in the work of Gellibrand and Henry Bond, this is a significant lacuna ${ }^{39}$.

Until 1639 when Theodore Haak and Marin Mersenne began correspondence, Hartlib and his friends were cut off from a particularly fruitful period of French intellectual life when the interlocking correspondence networks of Peiresc (until 1637) and Mersenne facilitated a free and rapid exchange of information in France and elsewhere in Europe, spreading in particular the explosive ideas of Galileo. The late 1620s and 1630s were also the period when Mersenne published most of his major works, when his correspondence with Descartes was well-established, and when a particularly interesting technical ad venture was under way as the optician Jean Ferrier attempted to grind hyperbolic lenses following Descartes precepts $^{40}$. Even so, it is a question how much of this activity would have been of interest to Hartlib at a period when his attention seems to have been concentrated on pansophia, educational reform and piety ${ }^{41}$. Philosophy seems never to have been much to his taste "Cartes [sic], Bisterfeld, Comenius begin their philosophy a priori. But they will find themselves deceived. Iungius goes more warily and derives a posterior, not caring so much to teach as first to find out truth that may not be gainsayd ${ }^{42 "}$. Empirical activity and research were acceptable, but mathematics, which was to become increasingly important to Mersenne in his later years, was also suspect. 'For as Cartes says it polishes mainly the Rational faculty. They may make themselves a new <actual> world of most curious and exquisite subtiltys in which there is no end. But then if it is not applied to some noble use in human life it is mere vanity. Therefore we see that Mersenne applies all the straine of his Mathematickes to the perfecting of Music $^{\prime 43}$.

This was to interpret Mersenne as if he was framed in Hartlib's mould rather than his own. Hartlib, haunted by a sense of man's fallen state and dependence upon God's providence could never have the same confidence in rational philosophy as Descartes, Mersenne or Gassendi. In his Ephemerides for 1639, 
immediately after notes which derive from the letters recently received by Haak from Mersenne, Hartlib comments.

The greatest philosophers should address themselves more to God in prayers and in holy life and so they should finde out more the secrets of Nature then ever they have done.

Eg we see it in Cartes glosses though his demonstrations bee never so punctual yet it will not doe the reason is because God is so little regarded in the matter as if human wit were able to accomplish all.

And it may be an obvious small matter is wanting which God hides of purpose from his and other $\exp <$ eriment $>\mathrm{s}^{44}$.

Hartlib, preoccupied with Pansophia and pressing inventions ${ }^{45}$ delegated the French correspondence to Haak. It was probably just as well.

\section{Pell, Mersenne, Haak and magnetism}

Mersenne, as noted above, had his own universalist dreams. Haak made an auspicious start to their correspondence by sending him a copy of John Pell's 'Idea of Mathematics't6. Although Mersenne thought this over ambitious, he was nonetheless highly interested and it also served to introduce Pell himself into the correspondence. Thereafter in the first group of letters to have survived, Pell and Mersenne exchanged almost exclusively mathematical letters in Latin, while Mersenne and Haak wrote about more general matters in the vernacular. In particular they wrote about a topic that fascinated them both - magnetism.

The exchange of information between London and Paris about magnetism in the early 1640s may be considered as one of the Hartlib group's most positive achievements in advancing knowledge since it brought to the notice of French scholars a major series of English observations of which they were entirely ignorant. These were the strictly controlled observations on magnetic compasses carried out in early 1634 by Henry Gellibrand that led him to postulate that changes in magnetic declination at London that had previously been thought to arise from observational errors, were in fact a function of time. This postulate, the first and major step towards formulation of the concept of 'secular variation', the 'variation of the variation' as contemporaries called it, had been difficult even for its formulators to accept, and they were led to it only because of a very specific concatenation of intellectual and social circumstances ${ }^{47}$. Some of this difficulty was already reflected in a note made by Hartlib in his Ephemerides in early 1630:

Gelebrands variation of the needle a Rare Experilent if 2. Or 3. More (one not knowing of the other) had lighted by the same rules or $<$ calculations> observations upon the same Experiment. Wats' ${ }^{\prime 48}$. 
Unknown to Hartlib, or indeed to the experimenters themselves, such a situation had by accident partly occurred. In the first letter that he wrote in response to Haak's initiative for a regular correspondence, Mersenne accompanied a request for information about a good lodestone in England with a copy of an essay on magnetism that he had written for the use of Athanasius Kircher then working on his Magnes ${ }^{49}$. To the amazement of Hartlib and his friends it revealed that Mersenne knew nothing either of Gellibrand's enunciation of the temporal change in declination or magnetic inclination ${ }^{50}$. This so impressed Hartlib that he made a special note of it 'Mersenne left out the 2 greatest Magneticall Experiments which Pell will suggest to him ${ }^{\prime 51}$. A copy of Gellibrand's book was immediately sent off and this, by mid-January 1640 (once Mersenne had had it translated) was in its turn causing astonishment in Paris ${ }^{52}$.

It also provoked reflection and experiment. Already in February the group in Paris were trying to asses different estimates of the declination there ${ }^{53}$, while Gassendi in Provence to whom Mersenne had communicated Gellibrand's book as he had news of it to several other of his correspondents such as Descartes, Antoine Vatier and Christophe Villiers, began to think that measurements of declination that he had made a few years earlier but had considered aberrant as they did not conform with received values might have had some sense after all ${ }^{54}$. By May, further astounded by more comparative declination figures, this time obtained by English navigators in the Davis Strait, Mersenne was also avowing that all this did seem to agree with the English theory that magnetic declination was diminishing with time ${ }^{55}$.

Mersenne's mildly favourable comments in May 1640 depended upon much the same criteria as those earlier enumerated by Hartlib - the concordance of several observations made independently and without knowledge of each other. Hartlib however seems not to have noted this agreement which, to the French philosophers, did not seem conclusive. Pierre Petit (1598-1677), was therefore set to work to make new measurements while Mersenne wondered if it would not be necessary to wait for at least ten or twenty years before being sure that the Paris declination value was really diminishing ${ }^{56}$. It was presumably in pursuance of this programme that twenty years later Pierre Petit, still working on declination, sent a measurement of it (c. 1 east) to Henry Oldenburg in October $1660^{57}$.

It was thanks to Hartlib's correspondence circle that news of the possibility that there was a temporal variation in magnetic declination reached Paris, and it was thanks to Mersenne's correspondence circle that, as Pumfrey has put it, "Gellibrand's work entered the publications of Kircher (1641), Fournier (1643), Descartes (1644), Grandami (1645), Gassendi (1649) and thence into the 'archive' of magnetic philosophy ${ }^{58 \prime}$. Declination however was not the only magnetic topic that exercised philosophers in France. Mersenne's letters to Haak and Pell are full of notes and requests for information on the behaviour of lodestones. But there was a basic difference between English 
and French investigators. Without actually setting out to look for them John Marr and Henry Gellibrand had obtained discrepant results when using the same compass in the same place but at an interval of some eleven years. Since there was apparently only one variable in the situation the anomaly demanded investigation. It should be noted however that the English investigators were concerned primarily with the behaviour of compasses. Elsewhere in Europe although investigators were also interested in compasses, they were far more interested in lodestones. Mersenne's magnetic programme, in so far as it was defined, was one to determine exactly how lodestones behaved, what their effects were, and how they could be modified. His objectives were firstly to destroy prevailing ideas that lodestones acted through supernatural forces of any kind, secondly to delineate exactly what they could and could not be expected to do on the basis of exact empirical knowledge. This done then the competing theories advanced about them by men such as Nautonnier, Cabeo, Kircher, Le Tellier Descartes, or Grandami could be assessed.

It was in the execution of this programme that Mersenne bombarded Haak and Pell with questions and observations. Iron was supposed to lose its magnetic force when it became red hot, but when only strongly heated it did not ${ }^{59}$. If Haak should find anywhere a reasonably priced magnet of three to ten ounces weight that unarmed lifted two to three times its own weight he should buy it immediately ${ }^{60}$. Would it be possible to borrow Samual Ward's remarkable lodestone that lifts twenty pounds to make experiments with it ? "If I had it with me for a month I should greatly increase my observations ${ }^{611}$. Experiments on lodestones such as immersing them in water or cutting pieces off them were reported ${ }^{62}$, and offers of help made. 'If Mr Bond would share the grounds for explaining the diminution, instead of injuring himself, we could perhaps help him somewhat ${ }^{\prime 63}$.

Quite how Hartlib's friends reacted to Mersenne's almost obsessive enthusiasm for the lodestone we do not know in detail. They seem to have tried to content him. Haak sent him a copy of Samual Ward's Magnetis reductorium theologicum tropologicum ${ }^{64}$, Mersenne having lost his own, and no doubt he reported observations. Perhaps too it was Mersenne's enthusiasm that fired Haak for his interest in the subject was to be durable. In the early 1680 s he was describing magnetic experiments to the Royal society, and so important did the subject become to him that a magnet figured prominently in his portrait painted between 1683 and his death in $1690^{65}$. It was also in the context of magnetism that some information about the Paris artisan world reached London, for this was an area in which the savants had a particular need of skilled craftsmen.

One of the phenomena that particularly intrigued Mersenne was the difference in the attractive power displayed by the same magnet when it was capped and when it was uncapped. These differences Mersenne wanted to assess in relation with the weight of the stone itself, and he eventually decided to base judgement of the quality of a lodestone purely on its attractive power when unarmed. 
If you can see the lodestone [of Samual Ward], that draws twentythree pounds capped, uncapped and bare, let me know how much it weighs and how much iron it attracts. I have the weakest of the said late Ward, but I was told that it attracted ten pounds of iron capped, and I find that it only draws seven, and that with difficulty... It is a strange business that uncapped it lifts no more than an ounce of iron, and capped it lifts 112 ounces. You see that the caps deceive us marvellously, and that it essential to see how much it carries completely bare to know whether they are good; that is why we prefer a natural stone, not shaped and naked, than one that is armed. And it will be good if it lifts as much as its own weight, especially if it a bit large: for example if it weighs one of several pounds, or at least half a pound and that it lifts more or less as much. I tell you this so that you will know how to choose $^{66}$.

Capping or arming a lodestone was a skilled and tricky art. It consisted in placing iron caps over the poles of the stone, which for reasons unknown to both artisans and savants, increased the lifting power of the instrument. According to William Gilbert an armed lodestone could lift three times as much weight as one unarmed and the iron of the caps should be of "the best steel, smoothed, shining and even". His only approach to an explanation however was that "Iron unites to an armed lodestone more firmly than to a lodestone; and on that account raises greater weights because the pieces of iron stick more pertinaciously to one that is armed ${ }^{67 \prime}$. Over a century and half later, J. A. Nollet did not offer even this much explanation despite recording a proportional difference of weight lifted by an unarmed and an armed lodestone that was far greater ${ }^{68}$. Despite the long elapse of time there had been little conceptual advance but some technical improvement. There had also been experiment. If Nollet could generalise that 'All lodestones do not have equal force: and there is hardly anything except the test that one makes, that can show what each stone can do; for the size, the colour, the degree of hardness etc are extremely equivocal indicators', it was because he had a century of observations of the kind made by Mersenne to draw on.

\section{Daniel Chorez}

"Also, there is no doubt but that the strength of a lodestone depends a great deal on the way in which it armed ${ }^{69} . "$ Nollet continued by naming the two instrument-makers, Butterfield and Joblot, who had high reputations for such work at the beginning of the $18^{\text {th }}$ century.
Mersenne had been equally admirative a century earlier of the instrument-maker Daniel Chorez. He is a maker of whom a great deal of what we can now know derives from the Hartlib papers. First mentioned in Mersenne's letters to Haak in 1640, news of Chorez and his abilities 
may have been disseminated throughout Hartlib's circle as he seems to have been visited whenever one of Hartlib's friends was in Paris. Thus in 1655 and 1656 news of him was sent to London by both Morian $^{70}$ and Erasmus Rasch ${ }^{71}$, while it was Henry Oldenburg who, in July 1659, reported his death some two or three months earlier ${ }^{72}$.

Like his older contemporary Philippe Danfrie, Chorez was a highly versatile craftsman of an original and innovative turn of mind. Like Danfrie he was a protestant, unlike Danfrie he was not married. According to Rasch he was self-taught ${ }^{73}$. Quite what Rasch meant by this is unclear for Chorez evidently had a sound training in one of the skilled mechanical crafts. Probably his basic commerce was in the making of traditional mathematical instruments such as astrolabes, but it is clear that he was alert to novelties. He is first heard of in 1616 as the maker of a sector, then still a new, unusual, instrument. Four years later he was already not only making telescopes and microscopes, but had also developed his own binocular version of both. To the engraving and optical skills that the making of these instruments implies, Chorez added those of the horologist and general mechanician for he also made pedometers, clockwork automata and lifting machines, besides being expert in capping lodestones. While it was the latter activity that probably most excited Mersenne who reported largely on their behaviour to Haak, Hartlib and his friends were probably more interested in a printed description of a machine devised by Chorez "for moving forces ${ }^{74 "}$. Of this device we know nothing (except that Descartes dismissed it as a "charlatannerie $\mathrm{e}^{75 \prime}$ ), unless it be the same as a machine mentioned by Oldenburg in 1659 and of which he sent Hartlib a copy of Chorez printed description.

Chorez' invention Oldenburg said was the same as that of Cressy Dimmock (fl. 1629-1660), that is a machine for increasing speed or force indefinitely. 'If it be true what is said in this paper about ye uses of such a machine, I think it is one of ye best inventions, yt ever was made. I should be glad to know, whether the author thereof has never been in England, or whether his name be not knowne there; and whether $\mathrm{Mr}$ Dymocks and hee were never acquainted together ${ }^{176}$. What Hartlib's answer to these questions was, we do not know, as his next three letters to Oldenburg are lost. To the second question however an affirmative answer can be given. Chorez name was, or at least had been, known in England thanks to Mersenne. We can also know something of his machine from a scribal copy of one of the two pamphlets that Hartlib had received describing "the addition to human force by a geometrical machine, which gives the force and speed so much sought after at all times, newly found out and brought into practice by D. Chorez ${ }^{77 "}$. The text that follows is a masterpiece of concealment. While making striking claims for the effects of his machine, Chorez contrives to reveal nothing more about it than that it is small, light, inexpensive to make, easy to use and adaptable to all kinds of existing machines that lift, pull or push something. Although nothing can be deduced from the text, the insistence that the device can be applied to so many tasks and other machines makes one 
suspect that it was a frame incorporating a series of pulleys.

Oldenburg's suggestion that Chorez' machine was similar to that of Cressy Dimmock raises interesting possibilities. The two inventions clearly had similar objectives and neither deserves to be referred to as a perpetual motion machine. In the description that Hartlib sent to Oldenburg of Cressy's machine (and on which Oldenburg presumably based his comments) ${ }^{78}$, Hartlib states "whereas it hath been for many ages ye study and endeavour of many ingenious persons to search and find out the way to bring strength and time together, or to make such an engine yt should keep ye same strength with other formerly knowne proportionable engins and yet, wthout applying more strength (as more or stronger men, horses, etc) to obtaine a considerable swiftness above yt former Engine, it stands compared wth; or (wch is all one) to keep the same degree of swiftness and obtain a strength considerably greater, yn ye former Engine hath:". This is little more than a longwinded expression of Chorez statement that he "has invented a machine which is so easy (to use) that one Person will effect more wth it, than two others with any other machine, whichever one chooses among those which have gone before, and that in the same time $\mathrm{e}^{79 \prime}$. If the two machines were really quite similar then the question arises as to whether the text sent by Oldenburg in 1659 was the same as, or a revised version of, that which Mersenne had sent in 1640 . If so then an influence from Chorez is possible since Dymock seems to have begun developing his machine in the mid- to late 1640s. But this influence would have been the reverse of that which had seemed possible to Oldenburg.

However exceptional he may have been, Daniel Chorez was not an isolated figure either as instrument-maker or as inventor. Inventions (in which projects for the organisation of resources and the exploitation of new ideas may be included) were of particular importance to Hartlib for it was through them that "Improvement" could take place. The technical innovations that Mersenne announced to Haak found a ready echo in London. What seemed noteworthy to Hartlib was recorded in his Ephemerides. In 1648, for example, Mersenne writes to Mr Haak that the draught of the flying machine out of Polonia is sent to him and that there is one with him who is fully persuaded that he can make the perpetuum mobile's0. Information was also passed on to his correspondents ${ }^{81}$. Reported in Mersenne's letters to Haak are devices as diverse as lenses and telescopes ${ }^{82}$, ways of finding longitude ${ }^{83}$ the manufacture of salt-petre from excrement $^{84}$, musical instruments ${ }^{85}$, and perpetual motion ${ }^{86}$. Othercorrespondents also reported on what could interest Hartlib. The connoisseur and diplomatic agent, Bathazer Gerbier, gave a rather negative account of Pascal's calculating machines ${ }^{87}$, and Oldenburg's pupil Richard Jones, 'knowing very well the love you bear to all sortes of ingenuities' wrote to describe a remarkable machine for lifting weights that he had seen near Tours, about the yield of grain, the popularity of mushrooms in France, and sent a whole selection of chemical and medical recipes ${ }^{88}$. 


\section{Jean Le Maire}

Many of the inventions reported to Hartlib were of little importance. They were ideas still to be worked out, curiosities with little or no application, devices so specific to a particular context that they could only with great difficulty, if at all, be adapted for use elsewhere. Most are mentioned once and then heard of no more. A few however provoked strong interestand a sustained enquiry. By way of example the numerous projects associated with Jean Le Maire may briefly be examined.

Jean Le Maire was neither philosopher nor instrument-maker; $\mathrm{He}$ was an inventive gentleman, an exponent of practical mathematics. Born in 1581 Le Maire, 'gentleman of the King's Bedchamber', proposed among other things the construction of a canal across France linking the Atlantic with the Mediterranean (a precursor of Riquet's canal du Languedoc), invented two new types of musical instrument, the Almerie (an anagram of his own name) and the Archivole, together with a new form of tablature and a new way of teaching music. The latter was linked with a method of language-teaching faster and easier than those in use, and with communication schemes based on universal language. In more traditional style he invented an universal surveying instrument - the Brachymere - and a navigating marvel - the Mecomere which, so Hartlib enthusiastically informed Lord Robartes "will give us the Longitude \& exactly both at Sea and Land so exactly that there shal bee no need any more the helpe of the Compass $^{89 \prime}$. All these inventions seemed so important that Hartlib was happy to obtain a copy of the Privilège accorded to Le Maire to publish his discoveries ${ }^{90}$.

Of all Le Maire's projects, those that came closest to success were those related to music. Perhaps this was because he was urged on in them by Mersenne who found them of special interest. He reported on them copiously and enthusiastically to Haak, Villiers, and Doni. Examples of both Le Maire's new instruments were made and played to the applause of a select audience in Paris by Jacques de Goüy (c. 1610-post $1650)^{91}$, who also published a sample of music in Le Maire's new notation ${ }^{92}$. At least one example of the archivole was sent to London, probably in $1648^{93}$. Destined for Charles I, the instrument survived the Interregnum to be purchased by Spring in $1659^{94}$. Thereafter "by My Ld. Brereton's care and expences made perfect; comprehending both and organ and a Concert of 5. Or 6. Viols in one, giving an excellent harmony, very solemne and most fit for religious musick", it was displayed to the Royal Society by Brereton in October $1664^{95}$.

Le Maire and his projects were brought to the attention of other English visitors in Paris in the 1640s. A copy of the 'Méthode pour la musique Almérique' among the papers of Thomas Hobbes was probably sent to him by Mersenne although it could have been acquired by Hobbes himself ${ }^{96}$. Bathazar Gerbier, by contrast, was primed by Hartlib, who sent him copies of the letters concerning Le Maire that had been received in 1640 . Gerbier however was already aware of Le Maire and unimpressed: 
For I have seen the Man long since, and was (with Honourable Countess of Claire) to see his Musicall instrument which is Harmonious, he hath many things jn his head, butt is not befriended by the best Professors of sciences and knowledge jn these parts, which want none that are excellent; he is a Narcissus of him selfe, and heady on his Inventions; he hath jnvented new names to the Notes of Musick, as iff you should say Ra, instead of
Ré, which passeth for idle among the Musicians.

Gerbier's judgement was perhaps not too harsh. When Haak enquired about Le Maire on renewing his correspondence with Mersenne in 1647, he must have received a disillusioned reply as he wondered in the following letter "what aim monsieur Le Maire has to be so niggardly of the public good in his inventions. What serves, and to whom, talent hidden in a pocket handkerchief ${ }^{97}$ ?"

\section{Differences and Influences}

What seemed incomprehensible to Haak, Hartlib and others of their circle dedicated to the publicising of new inventions and the free circulation of ideas, was perfectly evident to the inventors themselves. Inventions were made in the hope of gain. Privileges such as Le Maire obtained were needed to protect them; patronage and support were required to execute them. Lack of such things could inhibit discovery. This was exactly one of the reasons Oldenburg adduced in explaining to Hartlib why

I doubt very much, whether ye French will produce any great matter in point of Tubes, or chymistry, or any mechaniques; They have not yt required steddiness; and besides, they complaine of want of encouragement by men of power and means; witness they say, Monsr Chorez, who had the same invention, yt Mr Dymocks hath, but for want of assuring him of a recompence for putting it into practise and for discovering it to others, he took it wth him into his grave ${ }^{98}$.

Failure to follow through on an innovation, complaints about lack of support, preferring to allow a potentially useful idea die with its conceiver rather than make it freely available, all this was very different from the ideology of the Hartlib circle. Even if Oldenburg's comments derive in part from his chauvinism, the palpable disappointment with Paris revealed in his letters to Hartlib also reflects an only partially articulated recognition that philosophical activity there was not in the Hartlibian mode. Although Haak could assimilate Mersenne to his own circle, telling him in 1647 that he will be happy once again to serve him, nonetheless "the true end of my desire since yours have always been, and still 
remain so publicly, dedicated to the wellbeing and relief of this mortal state ${ }^{99 \prime}$, there was in fact no true sympathy. Mersenne's approach to nature was fundamentally far more rationalist than that of the Hartlib group. He was more interested in correspondence for the information of other savants than he was in correspondence to reform society.

For the purposes of immediate, daily practice then, Hartlib and his group were able to draw rather little from France. The correspondence with Mersenne failed to sustain itself, and that with Jean Doujat, who had written to Hartlib in August 1644 proposing a monthly correspondence of news about books, and people 'and generally to do all that is possible for me to content your curiosity in everything that does not concern politics', never even got off the ground ${ }^{100}$. Even so, some information did cross the Channel: Gassendi's biography of Peiresc (a pioneering essay in intellectual biography) was translated into English largely thanks to Hartlib, one major philosophical discovery (the temporal change in magnetic declination), owed its dissemination to the two groups, and another (experiments on the vacuum) also owed something to their activities. More generally there are some striking parallels that attest to a stimulus whether perceived or not. Hartlib's 'Office of address' project was largely based on the Bureau d'adresse of Théophraste Renaudot established in Paris in 1630 or perhaps a year of two earlier ${ }^{101}$. Hartlib's first information about it derived from a letter from Mersenne to Haak in 1639102, and it so impressed him that the following year he noted 'it were not amiss to send all manner of curious occasions and raritys to the Conference College at Paris that upon them they might have conferences, eg the prophet at Hamburg, the self-accusing man, Dr Mery's Serpent'103. A letter to an unnamed correspondent in January 1642 praised the weekly conferences highly ${ }^{104}$, and efforts to get more information were successful in 1647 or 1648 when Gerard Boate supplied copies of some of Renaudot's printed pamphlets about the Bureau ${ }^{105}$.

Renaudot's Bureau d'adresse was an existent institution offering a defined model to follow. Other parallels that can be adduced are more nebulous. The philosophical club founded in London "...for diversion sake in an innocent and virtuous manner ${ }^{106 "}$ in 1645 probably on the suggestion of Haak ${ }^{107}$, recalls not only the conferences of the Bureau d'Adresse, but also the numerous discussion groups of this kind that were already meeting in Paris, some of which, like those that met around Mersenne himself and around the Duchess d'Aiguillon in the Petit Luxembourg, specialised in topics of natural history and mathematics ${ }^{108}$. Optical activity in Paris, which like magnetism, linked savants with the mathematical instrument-makers, could also have provoked English emulation. In December 1639 Mersenne sent a description of the optical works of Daniel Aubery (1617-1645), who '...has had a forge made in his house, and has had 200 files constructed to make an instrument to observe asterisms with his telescopes. He employs 2 or 3 of the most able workman he could find to help him. He wants to make all sorts of conical telescopes but only for himself or for a few of his more particular friends ${ }^{109 \prime}$. 
Aubery had some success in his glass-works. By late January a good $2 \mathrm{ft}$ telescope had been prepared and he had completed a $2 \mathrm{ft}$ spherical lenses that showed Venus as large as the Moon; he was undertaking the grinding of hyperbolic lenses which he expected to have completed by the spring, and was planning a $10 \mathrm{ft}$ telescope $\mathrm{e}^{110}$; just over a year later Richard Reeve, the first outstanding English optician appears for the first time on record attempting to grind hyperbolical lenses for Charles Cavendish and John Pell both of whom were in direct contact with Mersenne. The coincidence is striking. Shortly afterwards it was probably Reeve who was installed in Jonathan Goddard's house making lenses that were used by the whole group of English astronomers centred on Gresham College, many of whom also belonged to the discussion group initiated by Haak ${ }^{111}$.

Parallels such as these are suggestive. Technical and intellectual transfer can take place at many levels of society, directly and indirectly. From Hartlib's papers it is clear that some specific techniques were transmitted from France to England during this period by the simple movement of a craftsman or an entrepreneur carrying the technique with them. A clear example is Pierre Blondeau's introduction of milled coinage $^{112}$. Other techniques could be transmitted by description verbal, written or pictorial, and Chorez' machine for augmenting human force may be one such. Other innovations however could be the result of emulation, of the stimulus provided by even vague reports of something similar being done elsewhere. All these kinds of innovation could benefit from the reassurance, emotional and psychological, which came from knowing that other groups of men were engaged in similar tasks and activities. The knowledge derived by the Hartlib circle from Paris, incomplete, discontinuous, often trivial though it was, operated in such ways. The empiricism displayed by French savants reinforced that of their English counterparts, striking inventions stimulated competition and improvement, institutional structures and research programmes supplied models for analysis and adaptation. Given the widely different ideological presuppositions of a providentialist Puritan and a Minime friar, it was probably inevitable that communication between Paris and London would be sporadic and subject to misunderstanding. Nonetheless some common ground could be explored; the results were not negligible. 
Appendix 1. Announcement of a machine by Daniel Chorez. Hartlib Papers 63/101/1A-2B. Copy in a scribal hand.

\section{L'Addition à la Force Humaine}

Par Machine de Geometrie, qui donne la force et la vitesse tant Cherchée en tout temps, trouvée nouvellement et mise en pratique par D. Chorez.

Lequel a inuenté une machine si facile, qu'une Personne fera plus d'effet auec icelle, que deux autres ne feront, avec une Autre machine, qu'elle qu' on voudra prendre d'entres celles qui on precede, Et ce en mesme temps.

Ladite machine est aisée à faire, et de peu de coust est facile à porter, n'occupe guerre d'espase, et peut estre facilement employee par toute sorte de personnes, à cause de la simplicité de son usage. Ce qu'elle difere de plusieurs autres machines es de peu devaleur et de façon: neanmoins c'est en cela que consiste l'invention de multiplier la force humaine : ilsera aise d'adiouster ceste difference et invention à toutes les machines de quoy les homes se servent pour lever, tirer ou pousser ce qu'on ne peut autrement.

Et pour monstrer qu'elle profitera à tous, le Roy en recou un tres grand profit sans fouler son people : car tous ateliers Royaux se feront plus aisement et prompement : le sel ne coustera pas tant amonter, par des rivières, les ponts et quais ne seront endommager par le renfort des chevaux, qu' on prend ordinairement pour monter les ponts et destroys dont de debris qui se fait fort souvent est reperé aux despens du Roy. Car les
Batteliers et autres personnes se pourront monter eux mesmes car ils cognoistront les cous leur ester plus doux et Favorable sans ester en peril de leur voiture et personnes.

Les canons et autres machines Royales seront maniez plus aisement, tant pour les monter et descendre, que pour les mener par lieux montagneux ou marescageux ou les chevaux ne les pouvent trainer, les hommes serviront et feront un effet plus merveilleux à peu de frais.

On pourra battre la poudre à canon fort aysement et par consequent éviter le grand malheur qui arrive quant le feu se met dans une grande quantité de poudre, qui cause la ruine de tout ce qui est voisin, et donne un grand avantage à l'ennemy. Car les matieres peuvent estre conservée fort aisement avec peu de hazard puis en pourra faire promptement de la poudre au besoin, par le moyen de ladite invention. Et quant il plaira au Roy de faire travailler aux mines qui se trouvent dans ses Roygaumes, ou à plusieurs canaux qui ont este proposer pour naviger d'un fleuve à l'Autre ou par la communication des deus [sic] mers par La France, ceste invention apportera l'espargne et la diligence predite.

Il se trouvera encore une infinité d'ouvrages, ou ladite invention ou partie d'icelle estant adaptée une personne fera plus d'ouvrage que ne souloient faire plusieurs.

Tout massons et Charpentiers empourront lever fait battre pilotes, et espuiser les eaux pour fonder les ponts et autres grans edifices, abregeront leur travail, et saveront beaucoup de despense. 
Tous ceux qui travaillent dans terre recevront un soulagement non pareil, car une grande partie de leur temps est employé à lever, soit terre ou eaux, ou pierre, ou metaux, et Autre chose pesante comme ardoise et charbon de mine.

La mesme invention server tous pressions, tant à vins qu'huile et à draps et à tirer le fil d'or et d'argent, de cuivre et de laiton de fer et sier, et toutes sortes de moulins à faute d'eaux ou de vent à tirer l'eau des lieux forts profonds, et la faire monter fort haut pour esteindre un grand feu qu'on n'ose approcher.

Tout Batteliers et Muniers pouront charger et decharger promptement leurs bateaux, nauires et galers, sortir des Havres, lever leurs ancres, leurs voilles et autres choses de semblable importance, ou la diligence est tellement resquise qu'une minute de retardement est souvent cause d'un naufrage. Et quant Cette invention leur sera bien cogneue et adaptée à la preparation convenable à leurs vaisseaux, ils advanceront leur chemin en temps de bonasse et se maintiendront contre le courant des mares, et contre le vent qui les pousse vers les costs et par ce moyen eviter un naufrage.

Ledit Chorez offer de monstrer l'effet de ce qu'il propose dans trois jours, estant asseuré (au prealable) d'une recompense honneste, avec le priuilege ordinairement octroye à tous ceux qui procure le profit du Roy et du public. Et peu de temps après metre en lumiere un livre auquel ladite machine sera figure et son usage descript, avec le moyen facile de l'adapter a toutes celles qui sont prevenues à sa cognoissance, les quelles apporteront la facilite et l'espargne predite.

Il demeure à Paris proche le Pont au Double du Coste de portau Foine.

Appendix 2. Extract from a draft or copy of a privilege for Jean Le Maire to publish his inventions. Hartlib Papers 18/2/45A-B.

Louis \& : a Nos Aimés et feaux Conseillers etc. Salut

Nostre bien aimé Iean Le Maire, Sieur de Vaude, Gentilhomme ordinaire de nostre Chambre, Nous a remonstré, que depuis XXXV ans ença il auroit grandement travaillé à $l^{\prime}$ Esclaircissemnt et Facilité tant des Arts liberaux, que Sciences des Mathematiques et Philosophie, et mesmes en avoit compose plusieurs Livres et traittés pour l'utilité publique, tant en Latin, qu'en François, par le moyen desquels on peut en fort peu de Temps venir à leur parfaitte cognoissance.

Entre autres : sur la Traduction des Langues, l'Alphabet universel; une Logique Physique demonstrative, vne Arithmétique nouvelle et facile. Un Traitté de la Musique lisante; avec des Notes, Characteres, et Preceptes, tant pour la Theorie, que Pratique d'icelle, autres que les Communs. Un traitté touchant la Constitution d'un instrument de Musique nouveau, nommé Almerie, approchant de la figure d'un Luth, sur lequel on peut exprimer facilement les trois genres de Musique, Diatonique, ChromatiqueetEnharmonique, avecl'Explication de la dite Musique, et la maniere de la pratiquer sur le dit Instrument et 
tous autres. L'Explication et l'Usage de l'Instrument a leuer les plans, dresser les Cartes Geographiques dit Mecomere; et d'un autre Instrument pour facilter la Navigation dit Brachymere. Certaines Cartes Geographiques, La Topographie de Languedoc et autres Provinces; les Descriptions et figures des Machines et Escluses desquelles il entend se server pour l'Execution du Traitté, que Nous luy avons fait, pour la Communication de la Mer Mediterranée, et de l'Ocean par la Rivière de Garonne et de l'Aude dans ledit pais de Languedoc'.

All which, Le Maire wishing to publish, he is accorded a 'privilège de protection' with a6000 livres fine for those who infringe it.

\section{Notes}

1. Henry Oldenburg to Samuel Hartlib 25 June 1659 printed from the Hartlib papers in Alfred Rupert Hall and Marie Boas Hall (eds), The Correspondence of Henry Oldenburg, i, 1641-1662, Madison \& Milwaukee, 1965, p. 270.

2. «Où on parle indifféremment de tout mais principalement des choses qui se passe dans le monde, et des livres curieux qui s'impriment de nouveau ». Oldenburg to Saporta 18 June 1659, ibid., p. 261. For Saporta see Pierre Chabbert, "Fermat à Castres ", Revue d'histoire des sciences et leurs applications, xx, 1976, p. 339 ; Gérard CREvon, « Riquet, le canal et les érudits de Castres » in Aux Sources du Canal du Midi (Société d'Histoire de Réveil Saint-Ferréol : les Cahiers d'Histoire, 18), 2014, p. 58-62.

3. A. R. Hall, M. B. Hall (eds), The Correspondence of Henry Oldenburg, op. cit., p. 261.

4. Oldenburg to Michaelis 26 August 1659, ibid., p. 240-241.

5. Thus, in the same letter to Hartlib (25 June) he states that Bressieux, an optical workman about whom Hartlib had inquired "is knowne here to be no great master, and esteemed to be one of those, yt talk of more yn they well know, and promise things they never performe"; A. R. HALL, M. B. HALl (eds), The Correspondence of Henry Oldenburg,op. cit., p. 270. On 8 November however, following a first meeting with Bressieux when Oldenburg saw his workshop, he had become "a great Artist' and Oldenburg was anxious that Hartlib help to obtain good, clear glass for his use", Oldenburg to Hartlib 8 and 12 November
1659, ibid., p. 327, 329. The "optician" in question was Etienne de Villebressieu (1626-1659), a mechanician, native to Grenoble who worked closely with Descartes and developed several ingenious machines particularly for raising water.

6. Persons skilled in affairs of state.

7. A. R. Hall, M. B. Hall (eds), The Correspondence of Henry Oldenburg, op. cit., p. 287, "words are femine, deeds masculine", a 16th century proverb that exists in Latin, French, Spanish, German, and English. For an interesting discussion see Teodolina BARolini, Dante and the Origins of Italian Literary Culture, New York, Fordham University, 2006, chap. 13. For similar comments by Walter Charleton in The Immortality of the Humane Soul (1657), on the tendency of French intellectuals to intemperate discussion see Aurélien Ruellet, La Maison de Salomon. Histoire du patronage scientifique et technique en France et Angleterre au XVII ${ }^{e}$ siècle, Rennes, Presses universitaires de Rennes, 2016, p. 61-63.

8. Harcourt Brown, Scientific Organisations in Seventeenth Century France (1620-1680), New York, Russell \& Russell Publisher, 1934 (reprinted) 1967), p. 87-89.

9. A. R. Hall, M. B. Hall (eds), The Correspondence of Henry Oldenburg, op. cit., p. 288.

10. Laurence W. B. BrocKLISs, French Higher Education in the seventeenth and eighteenth Centuries. A Cultural History, Oxford, Clarendon, 1987, p. 337-345.

11. Howard M. Solomon, Public Welfare, Science and Propoganda in seventeenth century France, the 
Innovations of Theophraste Renaudot, Princeton, Princeton University Press, 1972, p. 179-180.

12. For an agreeable survey of the subject and its main protagonists, see Laurence CARLIN, The Empiricists: a guide for the perplexed, London, New York, Continuum, 2009, chapters 1 to 7.

13. H. Brown, Scientific Organisations, op. cit. ; René Taton, Les origines de l'Académie Royale des Sciences, Paris, Palais de la Découverte, 1966 ; Roger HaHn, The Anatomy of a scientific Institution, the Paris Academy of Sciences, 1666-1803, Berkeley, Los Angeles \& London, University of California Press, 1971 ; Trevor McClaughlin, « Une lettre de Melchisidech Thévenot », Revue d'Histoire des Sciences, xxvII, 1974, p. 123-126 ; id., "Sur les rapports entre la Compagnie de Thévenot et l'Académie Royale des Sciences ", Revue d'histoire des sciences, xxVIII, 1975, p. 235-242.

14. For empiricism in Gassendi's philosophy see Barry Brundell, Pierre Gassendi, from Aristotelianism to a new natural philosophy, Dordrecht, D. Reidel, 1987, especially chapter IV and p. 139. L. CARlin, The Empiricists, op. cit., ch. IV. For examples of Gassendi's empirical work see: Anthony Turner, Nadine Gomez, Pierre Gassendi, explorateur des sciences, Digne-lesBains, Musée de Digne, 1992. Anthony J. Turner, « Pierre Gassendi, astronomer natural philosopher ", Interdisciplinary Scientific reviews, XIX, 1994, p. 135-139. For Descartes see Desmond M. Clarke, Descartes' Philosophy of Science, Cambridge, Cambridge University Press, 1982, chap. 2 and p. 200-202.

15. Reijer HooykaAs, « Pierre de la Ramée et l'empirisme scientifique au $\mathrm{xVI}^{\mathrm{e}}$ siècle " in $L a$ Science au seizième siècle. Colloque International de Royaumont, 1-4 juillet 1957, Paris, Hermann, 1957, p. 299-313. Palissy's work, as presented in the version of his Recepte véritable... (1563) published in 1636 provoked considerable interest among Hartlib and his friends when Mersenne brought it to Haak's attention as being similar to the work of Gabriel Plattes, Mersenne to Haak 24 November 1639 in Cornelis de WAARD et al (eds), Correspondance du P. Marin Mersenne, 17 vol., Paris, CNRS, 1933-1988, viII, 637. Discoveries concerning Palissy in the 1980s are resumed with bibliography in Revue de l'Art, 1987. For the use of Palissy by Hugh Plat, the second edition of whose works may have been promoted by the Hartlib group see Alan Debus, « Palissy, Plat and English agricultural chemistry in the 16th and 17th centuries ", Archives Internationales d'Histoire des Sciences, xxI, 1968, p. 67-88 and further comments in Malcolm THIск, Sir Hugh Plat: the Search for
Useful Knowledge in Early Modern London, Totnes, Prospect Books, 2010.

16. The locus classicus for Peiresc's life is the detailed account published five years after his death by GAssend, Vir illustris Nicolai Clavdii Fabrici de Peiresc senatoris aquisextiensis $v$ ita ..., Paris, Sebastiani Cramoisy, 1641 and several later editions which are enumerated in A. TuRnER, N. Gomez, Pierre Gassendi, op. cit., p. 57. Gassendi's life is now conveniently available in a recent French translation by Roger Lassalle, Un savant, une époque : Peiresc 1580-1637, Paris, Belin, 1992. Older but still worthwhile are Pierre Humbert, Un amateur, Peiresc (1580-1637), Paris, 1933 and George Cahen-Salvador, Un grand humaniste, Peiresc 1580-1637, Paris 1951. More recent interpretations are Marc Fumaroli, « Nicolas Claude Fabri de Peiresc, prince de la République des Lettres » in Peiresc - Gassendi, l'humanisme triomphant dans la Provence Baroque, Brussels, Fondation Claude-Nicolas Fabri de Peiresc, n.d. [1993] reprinted in a revised version in Marc Fumaroli, La République des lettres, Paris, Gallimard, 2015, chap. 2, and the indispensible study by Peter Miller, Peiresc's Europe. Learning and Virtue in the Seventeenth century, New Haven \& London, Yale University Press, 2000, used here in the French translation by Pierre-Emmanuel DAUZAT, L'Europe de Peiresc, savoir et vertue au XVII siècle, Paris, Albin Michel, 2015.

17. This point is amply illustrated by Agnès Bresson in her edition Nicolas-Claude Fcabri de Peiresc, Lettres à Claude Saumaise et son entourage (1630-1637), Florence, Léo S. Olschki, 1992, p. XLIII-XLVII.

18. Anne Reinbold «Peiresc et les peintres de son temps » in Anne Reinbold (ed.), Peiresc ou la passion de connaître. Colloque de Carpentras, novembre 1987, Paris, Vrin, 1990, p. 187-204, who shows how in his desire for absolute verity in the depiction of things, Peiresc was at cross-current with prevailing ideas about 'perfection' in painting.

19. For astronomy see Frederic J. Baumgartner, "The origins of the Provençal school of astronomy », Physis, xxviII, 1991, p. 291304 ; id., "Galileo's French correspondents ", Annals of Science, 45, 1988, p. 169-182 ; Albert VAN Helden, "Gassendi and the telescope : towards a research community ", Annales de Haute Provence, CCCXXI-XXII, 1992-1993, p. 329-339; William B. Ashworth jr, « The map of the Moon of Gassendi, Peiresc and Mellan », ibid., p. 341-52 ; for vision, Robert A. НАтсн, « Coherence, correspondence and choice : Gassendi and Boulliau on light and vision », ibid., p. 365-385 ; A. Turner, N. Gomez, 
Pierre Gassendi, op. cit., p. 111, 117. Numerous, quite detailed, accounts of Peiresc's empirical investigations are given in Gassendi, Vir illvstris..., op. cit.

20. Smith an orientalist and theological controversialist notable for his debates with the quakers John Bunyan and George Whitehead in 1659 was, like More and Widdrington, a Fellow of Christ's College, Cambridge where he was also librarian from 1659 until his death. For his career see Paul HAmmond, « Smith, Thomas (1624-1661) », Oxford Dictionary of National Biography, Oxford University Press, 2004, [http://www.oxforddnb.com/view/ article/68258].

21. A contentious Fellow of Christ's College Cambridge who in October 1650 had been appointed University Orator. For his career see Hugh DE QUEHEN, "Widdrington, Ralph (1614/15-1688) », Oxford Dictionary of National Biography, Oxford University Press, 2004; online edn, Jan 2008 [http://www.oxforddnb. com/view/article/29355].

22. (1614-87), the well-known platonist philosopher and also a Fellow of Christ's College and in contact with Hartlib. In 1651 his only publications were a number of philosophical poems. Since in $1650-51$ he was heavily engaged in controversy with the alchemist and poet Thomas Vaughan it is unlikely that he could have offered Smith much assistance. See Oxford Dictionaty of National Biography, Oxford University Press, 2004.

23. A cheap duo-decimo edition was indeed published in 1651 by Adriaan Vlacq in the Hague.

24. Thomas Smith to Samuel Hartlib 3 September 1651. Hartlib Papers 15/6/255A-26B. Rather little is known of Rand but see Charles Webster, The Great Instauration. Science, Medicine and Reform 1620-1660, London, Duckworth, 1975 (new ed. 2002), for his proposals for a new college of physicians in London. His attention had been drawn to the Vita...Peiresc as a subject of translation by Worsley who combined admiration for Bacon with admiration for the experimentalism of Peiresc and Gassendi. See Thomas Leng, Benjamin Worsley (1618-1677). Trade, Interest and the Spirit in Revolutionary England, Woodbridge, The Royal Historical Society and the Boydell Press, 2008, p. 25. For Rand's relation with Evelyn see Gillian DARLEY, John Evelyn, living for ingenuity, New Haven \& London, Yale University Press, 2006, p. 146-147. Geoffrey Keynes, John Evelyn, A Study in bibliophily with a Bibliography of his Writings, $2^{\text {nd }}$ edition Oxford, Oxford University Press, 1968, p. 8, 283.

25. Joseph Scherpereel, « Peiresc et la musique » in A. Reinbold (ed.), Peiresc ou la passion de connaître, op. cit., p. 153-185, p. 157.
26. Mersenne was also less good natured than Peiresc. For a comparison and account of their collaboration see Armand Beaulieu, « Mersenne rival de Peiresc ? ", in A. Reinbold (ed.), Peiresc ou la passion de connaître, op. cit., p. 23-40.

27. De Subtilitate..., 1550 and many later editions.

28. Magia naturalis, Naples, 1558 and numerous later editions. English translation London 1658 reprinted in facsimile with an introduction by Derek Price, The Collector's Series in Science, I, New York, The Smithsoninan Institution, 1957.

29. «Mais il n'y a pas de plaisir à cela, si l'on ne rencontre quelques autres, qui ayant le mesme dessein : car il y a des expériences à faire de Médecine, de Chymie, de Labourage, des méchaniques, etc ; ce qu'un homme seul ne peut pas faire, s'il n'estoit gagé à cela par un Roy ou une République ». Mersenne to Haak 22 November 1640 ; C. de WAARD et al (eds), Correspondance $d u$ P. Marin Mersenne, op. cit., XI, p. 426-27, Ix, p. 409, 20 March 1640 where he dilates on how he hates all deceptions that savants are forced to spend time combating, " et si l'on me vouloit seconder et ayder, je purgeroit Pline, Cardan, Baptista Porta et tous les autres de toutes les faussetés qui s'y trouvent ».

30. Roger FRENCH, Andrew Cunningham, Before Science, the Invention of the Friars' Natural Philosophy, Aldershot, Ashgate, 1996.

31. Hilary CAREy, Courting Disaster: Astrology at the English Court and Universities in the Later Middle Ages, London, Palgrave Macmillan, 1992. Despite its title, the book also contains a good deal of information about France.

32. For a more detailed account of Late Medieval developments see Anthony J. Turner, Mathematical Instruments in Antiquity and the Middle Ages, London, Vade Mecum Presss, 1994, chap. 3. For Renaissance mathematics, Paul Lawrence Rose, The Italian Renaissance of Mathematics. Studies on Humanists and Mathematicians from Petrarch to Galileo, Geneva, Droz, 1975. For Renaissance workshops, Anthony J. Turner, « Gli Strumenti scientifici » in Storia della Scienza, IV Medioevo, Rinascimento, Rome, Enciclopedia Italiana, 2001, chap. xviII. For practical mathematics and practitioners see Eva Germaine RIMINGTON Taylor, The Mathematical Practitioners of Tudor and Stuart England, Cambridge, the Institute of Navigation/ Cambridge University Press, 1954 ; Stephen Andrew Johnson, "Making mathematical practice : gentlemen, practitioners and artisans in Elizabethan England ", unpublished PhD thesis Cambridge 1994 ; Thomas B. Settrle, "The Tartaglia Ricci problem : towards a study of the 
technical professional in the 16th century" in Istituto Veneto di Scienze, Lettere ed Arti, Culttura, Scienze e Techniche nella Venezia del Cinquecento. Atti del Convegno...Giovani Batista Benedetti e il suo tempo, Venice, Istituto Veneto di Scienze, 1987 , p. 217-226. For warfare see Jim BENNETT, Stephen JoHnson, The Geometry of War 1500-1750, Oxford, Museum of the History of Science, 1996. The relevant recent collective work edited by Lesley B. Cormack, John A. Schuster, Steven A. Walter, Mathematical Practitioners and the transformation of natural knowledge in Early Modern Europe, Berlin, Springer, 2017 unfortunately was published after this essay was completed.

33. John Davis, "Fit for a king. Decoding the Sloane astrolabe and other English astrolabes with 'quatrefoil' retes », Medieval Encounters, xxviI, 2017, p. 311-354 ; id., "A royal English medieval astrolabe made for use in Northern Italy ", Journal for the History of Astronomy, xLVIII, 2017, p. 3-32 ; Silke AcKermanN, John Cherry, "Richard II, John Holland and three Medieval Quadrants ", Annals of Science, LVI, 1999, p. 3-23 ; Catherine EAGLETon, "A king, two lords, and three quadrants", Early Science and Medicine, xvI, 2011, p. 200-217 ; John DAvis, "The Chetwoode quadrant, a medieval unequal-hour Instrument », Bulletin of the British Sundial Society, xxviI (2)i 2015, p. 2-6 ; Emmanuel Poulle, Un Constructeur d'instruments astronomiques au $\mathrm{XV}^{e}$ siècle : Jean Fusoris, Paris, Librairie Honoré Champion, 1963.

34. Silvio A. BedinI, "Falconi, renaissance astrologer and astronomical clock and instrument maker », Nuncius. Annali di Storia della Scienza, xIx 2004, p. 31-76 ; Gerard L'Estrange Turner, “The Florentine workshop of Giovan Battista Giusti, 156-1575 », Nuncius. Annali di Storia della Scienza, x, 1995, p. 131-172.

35. For a fuller treatment of Danfrie see Anthony J. Turner, "Paper, print and mathematics : Philippe Danfrie and the making of mathematical Instruments in late 16th Cenntury Paris ", in Christine Blondel, Françoise PAROT, Anthony Turner, Mari Williams (eds), Studies in the History of Scientific instruments, London and Paris, Rogers Turner Books, 1989, p. 22-42. Some supplementary information is given in Anthony J. Turner, "Mathematical Instrumentmaking in Early Modern Paris », in Robert Fox and Anthony Turner (eds), Luxury trades and Consumerism in Early Modern Paris: Studies in the History of the Skilled Workforce, Aldershot, Ashgate, 1998, p. 69-73.

36. HP 43/19A.

37. Ephemerides 29/3/64A.
38. For an account of Morin's life and a brief introduction to his longitude ideas see Monnette Martinet, "Jean Baptiste Morin » in Pierre Costabel and Monnette Martinet, Quelques Savants et amateurs de science au XVII siècle (Cahiers d'Histoire et de Philosophie des Sciences, n.s. 14), Paris 1986, p. 69-88. For detailed discussions see Jean PARÈs, « Jean Baptiste Morin (1583-1656) et la querelle des longitudes de 1634 à 1647 », thèse de troisième cycle, École des Hautes Études en Sciences Sociales, n.d. [1976], and the important recent discussion in A. Ruellet, La Maison de Salomon, op. cit., ch. IV.

39. News of Morin finally reached the Hartlib circle in March 1640 when Mersenne sent Haak a copy of the title page of Morin's latest publication on longitude, following it in September with the book itself, de longitudinibus dignoscendis Mersenne added that it was quite easy to obtain Morin's other works as their author sold them himself.4 September 1640, C. de WAARD et al (eds), Correspondance du P. Marin Mersenne, op. cit., IX, p. 414. By this time however, Morin's ideas had been discredited and he had lost official support.

40. This episode is described by William R. SHEA, "Descartes and the French artisan Jean Ferrier", Annalil dell'Istituto e Museo di Storia della Scienza di Firenze, vII, 2, 1982, p. 145-159. It may be noted that if the search engine of the electronic edition of Hartlib's papers is reliable, then there is no mention of this episode, nor of Ferrier, in the whole collection, this striking omission may reflect a desire to keep the whole endeavour secret.

41. Stephen Clucas, "Samuel Hartlib's Ephemerides, 1635-1659, and the pursuit of scientific and philosophical manuscripts: the religious ethos of an Intelligencer", The Seventeenth Century, vI, 1991, p. 33-55, who after a clear exposition of Hartlib's religious motivations, argues (p. 38) for a reorientation in his interests from theology and devotion towards more secular concerns in learning and technical development from c. 1640 onwards.

42. Ephemerides 1639 30/4/3A.

43. Ephemerides 1640 30/4/46B.

44. Ephemerides 1639 30/4/26B.

45. C. Webster, The Great Instauration, op. cit., p. 53.

46. On this see Charles Webster, Samuel Hartlib and the Advancement of Learning, Cambridge, Cambridge University Press, 1970, 15-17.

47. These are defined and explained by Stephen Pumfrey, “ ‘O Tempora, O magnes!'. A Sociological analysis of the discovery of secular 
magnetic variation", British Journal for the History of Science, xxII, 1989, p. 181-214.

48. Ephemerides 29/313A

49. Published at Rome in 1641 with several later editions. See John Fletcher, Teinhard Dieterle, Gerhard Römer and Ulf Scharlau, Universale Bildung im Barock. Der Geleherte Athanasius Kircher, Kardlsruhe, Badische Landesbibliothek, 1981, p. $75-81$.

50. Pell to Mersenne 21 November 1639, C. de WAARD et al (eds), Correspondance du P. Marin Mersenne, op. cit., vIII, p. 632.

51. Ephemerides 1639, 30/4/25B.

52. Mersenne to Haak 15 January 1640, C. de WAARD et al (eds), Correspondance du P. Marin Mersenne, op. cit., IX, p. 135.

53. « Nous sommes icy depuis peu en grand contestation, si nostre declinaison de Paris est de 4 degrez et $1 / 2$...ou si elle n'est que 3 degrez... », Mersenne to Haak 25 February 1640. C. de WAARD et al (eds), Correspondance du P. Marin Mersenne, op. cit., IX, p. 135.

54. C. de WAARd et al (eds), Correspondance $d u$ P. Marin Mersenne, op. cit., viII, p. 633. A. Turner, N. Gomez, Pierre Gassendi, op. cit., p. 161.

55. Mersenne to Pell 12 May 1640, C. de WAARD et al (eds), Correspondance du P. Marin Mersenne, op. cit., Ix, p. 311.

56. Mersenne to Haak, 4 March 1640, ibid., IX, p. 311. Mersenne was perhaps influenced here by the view of Christophe Villiers at Sens who in a letter dated three days earlier had councelled reserving judgement as '...such observations want more time to be decisive" "...telles observations veulent plus de tems pour la decision", ibid., IX, p. 164.

57. A. R. Hall, M. B. Hall (eds), The Correspondence of Henry Oldenburg, op. cit., p. 400401. It is surely significant that there is a copy of this observation in the HP 67/49/3A-B.

58. S. Pumfrey, “' 'O Tempora, O magnes!', op. cit., p. 209. In a second study Pumfrey has described and assessed the significance of magnetic work in the Hartlibian programme generally and, from a slightly different perspective, has recounted its transmission to Mersenne and other continental scholars. Stephen Pumfrey, " 'These 2 hundred years not the like published as Gellibrand has done de Magnete': the Hartlib Circle and Magnetic Philosophy", in Mark Greengrass, Michael Leslie, Timothy Raylor (eds), Samuel Hartlib and Universal Reformation, Cambridge, Cambridge University Press, 1994, chapter 13, p. 247-267.
59. To Haak 15 January 1640, C. de WAARD et al (eds), Correspondance du P. Marin Mersenne, op. cit., IX, p. 14.

60. To Haak 20 January 1640, ibid., IX, p. 39-40.

61. To Haak 10 December 1639, ibid., VIII, p. 683. "Si je l'avois eüe un mois, j'augmenterois mes observations de beaucoup ». Although Ward agreed to the demand (Hartlib papers 34/6/12A$13 \mathrm{~B})$, the conditions he laid down seemed so onerous to Mersenne that he withdrew his request. His English correspondents continued to try to satisfy him. Eventually Mersenne acquired another (though less good), of Ward's lodestones. This however was a disappointment - "uncapped it is worthless" ("désarmé il vaut rien").

62. To Haak 10 March 1640, ibid., IX, p. 404 ; 12 May 1640, ibid., IX, p. 305.

63. To Pell c. 12 May 1640, ibid., IX, p. 312. « Si M. Bondus vouloit faire part de son fondement pour la raison de la diminution, au lieu de luy nuire [here used in the sense of detracting from his reputation] nous pouvions peut-estre l'ayder en quelque chose ".

64. London 1637, with another edition in 1638. An English translation by Sir Harbottle Grimston was published in 1640 .

65. Pamela R. Barnett, Theodore Haak, F. R. S. (1605-1690): the first German translator of Paradise Lost, The Hague, Mouton \&. Co. 1962, p. 152. [https://pictures.royalsociety.org/imagers-9712].

66. To Haak 28 November 1640, C. de WAARD et al (eds), Correspondance du P. Marin Mersenne, op. cit., IX, p. 429-430. « Si vous pourrez voir l'aymant [de Ward] désarmé et à nud, qui tire 23 <livres> armé, mandez moy combien il pèse, et combien il tire de fer. J'ai le plus foible du mesme deffunct Ward, mais on me disoit qu'il tiroit $10<$ livres $>$ de fer estant armé, et je trouve qu'il n'en tire que 7 , et encore à peine : ... C'est chose estrange, que désarmé il ne lève pas (plus) qu'une once de fer, et armé il lève 112 onces. Vous voyez que les armés trompe merveilleusement, et qu'il faut nécessairement voir, combien ils portent tout nus, pour sçavoir s'ils sont bons : c'est pourquoi l'on ayme mieux en brute, non taillé, et tout nu, qu'un armé. Et il sera bon, s'il tire aussi pesant comme luy, particulièrement s'il est un peu gros : par exemple s'il pèse une ou plusieurs livres, ou du moins une demie-livre et qu'il lève a peu près autant. Ce que je vous dis, affin qu'aux rencontres vous sachiez bien choisir ».

67. William Gilbert, De Magnete, London, Peter Short, 1600, Chiswick Press translation, 1900 (reprinted 1958), p. 87. 
68. Jean Antoine Nollet, Leçons de physique expérimentale, VI, Paris, 1764 and several other editions. The copy used here is the sixth, published in 1768, the relevant passage being on pp. 166-67. The example Nollet gives of a lodestone in his own possession for some fifteen years that unarmed lifted half an ounce, but armed raised twenty-seven and a half ounces, was clearly exceptional and cited for this reason.

69. Ibid., p. 169. "Il ne faut pas douter aussi que la puissance d'u aimant ne dépende beaucoup de la façon dont il est armé ».

70. HP 56/1/24A.

71. HP 56/41/2A \& 56/1/25A.

72. A. R. Hall, M. B. Hall (eds), The Correspondence of Henry Oldenburg, op. cit., p. 278.

73. To Hartlib 22 May 1655, HP 26/41/2A. For documentation of this account of Chorez and further details see Turner in Fox \& Turner (n. 35).

74. «L'affiche pour les forces mouvantes ». Mersenne to Haak 25 February 1640. Corr. ix 134.

75. To Mersenne 29 January 1640, C. de WAARD et al (eds), Correspondance du P. Marin Mersenne, op. cit., IX, p. 87-88.

76. A. R. Hall, M. B. Hall (eds), The Correspondence of Henry Oldenburg, op. cit., p. 278, 26 July 1659. For Dimmock see Mark GREENGRAss, in Oxford Dictionary of National Biography, Oxford University Press, 2004 [http://www.oxforddnb. com/view/article/54119].

77. H.P. 63/101/1A-2B. In the transcribed version of this document included in the electronic edition of the papers the name is given as Chorer, but this is clearly a misreading. See Appendix 1

78. 17 November 1659, A. R. Hall, M. B. Hall (eds), The Correspondence of Henry Oldenburg, op. cit., p. 189-190. Hartlib who had supported Dymock while he developed his machine had a strong financial interest in it.

79. Appendix 1, paragraph 2.

80. Ephemerides 31/22/1B. The "Polish flying machine" is the "flying Dragon" of Tito Livio Buratini (1617-1687) who developed his ideas for a man-powered flying machine in Warsaw in $1647 / 48$. News of the attempt was first sent to Paris in a letter from Pierre Desnoyers to Roberval 4 December 1648, C. de WAARD et al (eds), Correspondence du P. Marin Mersenne, op. cit., xv, p. 560-563, and futher information followed, reported on to Haak by Mersenne. For details of the machine see Clive HART, The Prehistory of Flight, Berkeley, University of California Press, 1985, p. 134-145. René TAToN, « Le 'Dragon volant' de Burattini », Revue des sciences humaines, ClXxXVI-VII, 1982-1883, p. 45-66 ; id., " Nouveau document sur le « Dragon volant » de Burattini »,
Annali dell 'Istituto e Museo della scienza di Firenze, VII (1), 1982, p. 161-167.

81. See for example a letter to Lady Barrington, 21 August 1640 reporting news from France.

82. 24 November 1639, C. de WAARD et al (eds), Correspondence du P. Marin Mersenne, op. cit., VIII, p. 638 ; 18 December 1639, ibid., VIII, p. 693 ; 31 December 1639, ibid., viII, p. 722.

83. 20 January 1640, ibid., Ix, p. 52 ; 1 March 1640, ibid., IX, p. 171 ; 4 March 1640, ibid., IX, p. 178.

84. 12 February 1640, ibid., IX, p. 107.

85. 20 March 1640, ibid., Ix, p. 406-507.

86. 12 May 1640, ibid., IX, p. 306.

87. HP $10 / 2 / 12 B-13 A$. His acount is transcribed and discussed in Mark GREENGRAss, "Sir Bathazer Gerbier et la machine à calculer de Pascal", Courrier du Centre International Blaise Pascal, XIX, 1997, p. 10-16. For Gerbier's career see Jeremy WARD in Oxford Dictionary of National Biography, Oxford University Press, 2004 [http:// www. oxforddnb. com/view/article/10562].

88. HP 14/3/2A-B, 7 July 1657 ; HP 44/9/1A$2 B$.

89. HP 7 /55/1B, 10 March 1640.

90. HP $18 / 2 / 45 A-B$, partly transcribed in Appendix 2. The document was no doubt supplied to Hartlib by Mersenne but it was not, as the electronic edition describes it, a 'petition: Mersenne to ( ? Louis)'.

91. For whom see Edmond VANDERstraeten, Jacques de goüy Musicien du dix-septième siècle, Antwerp, J. E. Buschmann, 1863.

92. Albert Cohen, "Jean Le Maire and La Musique Almérique ", Acta Musicologica. Revue de la Société Internationale de Musicologie, xxxv, 1963, 175-9 ; James R. KNowLson, « Jean Le Maire and the 'musique almérique': a set of unpublished documents ", Acta musicological, XL, 1968, 86-9 who offers most of the relevant documents from the Hartlib Papers [onward : HP].

93. There are numerous references in $\mathrm{HP}$, but see in particular 63/8/51-6B, "Extracts concerning Jean Le Maire's Musical Inventions".

94. HP 29/8/4B.

95. Oldenburg to Boyle 13 October 1664 who concludes his description of the occasion "I must confesse it transports me, and cannot but exceedingly please him yt playes upon it, hearing himselfe alone perform a whole consort of viols"? The Correspondence of Henry Oldenburg, op. cit., II, p. 251-152.

96. British Library ms Harley 6796 no 20 ff 17577, see Cohen (n. 92).

97. Haak to Mersenne 6 August 1647, C. de Waard et al (eds), Correspondance du P. Marin Mersenne, op. cit., xv, p. 353. «Quel but Monsieur 
le Maire avoir d'estre si chiche de ses inventions au bien public. A qui et a quoy sert le Talent dans le Mouchoir ? ».

98. 2 July 1659, The Correspondence of Henry Oldenburg, I, op. cit., 278.

99. 5 June 1647, C. de WAARD et al (eds), Correspondance du P. Marin Mersenne, op. cit., XV, p. 248.

100. Doujat to Hartlib 26 August 1644. HP 9/3/3A

101. H. M. Solomon, Public Welfare, op. cit., p. 39, 94-95, 218-219; C. WeBster, The Great Instauration, op. cit., p. 68.

102. Ephemerides $30 / 4 / 33 \mathrm{~A}$.

103. Ephemerides 30/4/48B.

104. 27 January 1642 "ad $\mathrm{Mr}$ Sto", HP 7/27/1A-B.

105. They are now in HP $48 / 7$ and $48 / 8$. Other relevant documents occur in the same dossier and also in 36/1/17A and 58/3A-4B.

106. Anthony Wood, History and Antiquities of Oxford (ed J. Gutch), Oxford, Clarendon Press, 1786, II, p632-633.

107. P. R. BARnetT, Theodore Haak, op. cit., p. 78: the author suggests that it was the setting up of these meetings that stimulated Haak to reopen correspondence with Mersenne in 1647.

108. Several of these groups are surveyed in Simone Mazauric, "Des académies de l'âge baroque à l'Académie royale des sciences " and Katia BÉGuIN, "L'académie du Grand Condé : un asile de liberté scientifique ? ", both in Christiane Demeulenaere-Douyère, Eric Brian (eds), Règlement, usages et science dans la France de l'absolutisme... actes du colloque international... Paris 8-10 juin 1999, London, Paris \& New York, Editions Tec \& Doc, 2002, p. 13-36.
109. Mersenne to Haak, 31 December 1639. Corr. viii 723.

110. Mersenne to Haak 20 January 1640, C. de WAARD et al (eds), Correspondance du P. Marin Mersenne, op. cit., IX, p. 41. The 12 February 1640 however Mersenne reported to Haak that Aubery was having considerable difficulties in his polishing, ibid., Ix, p. 108. Five years later all activity would be stopped when Aubery, aide-de-camp to the Duc d'Enghien, was killed during the battle of Nordlingen. Louis Aubery Du-Maurier, Histoire de l'execution de Cabrieres et de Merindol et d'autres lieux de Provence, particulierement deduite dans le plaidoye qu'en fit l'an 1551 par le commandement du du roy Henry II. et comme son advocat general en cette cause Jacques Aubery etc. pour traitter de la paix l'an 1555. Etc, Paris, Sébastien Cramoisy, 1645.

111. A. D. C. Simpson, "Richard Reeve - the English Campani - and the origins of the London Telescope making tradition", Vistas in Astronomy, XXVIII, 1985, p. 357-365, p. 358.

112. Discussed in detail in C. WeBster, The Great Instauration, op. cit. Although stages of Blondeau's activities are recorded by documents in $\mathrm{HP}$, it is not entirely clear of how much help members of the circle were to him. Blondeau himself may be the Parisisian instrument-maker who received a place in the Louvre in February 1642, but is not otherwise known as an active maker. Having returned to France in 1660, Blondeau rejoined the Mint in 1662 where he was visted by the Dutch painter Willem Schellincks. See Maurice Exwood, H. L. LEHAM (eds), The Journal of Willem Schellincks Travels in England 1661-1663 (Camden Society 5th series, 1), London, Royal Historical Society, 1993, p. 17. 